Nutrition Research Reviews (2018), 31, 248-255

doi:10.1017/S0954422418000094

(C) The Authors [2018]. This is an Open Access article, distributed under the terms of the Creative Commons Attribution licence (http:// creativecommons.org/licenses/by/4.0/), which permits unrestricted re-use, distribution, and reproduction in any medium, provided the original work is properly cited.

\title{
Insects as sources of iron and zinc in human nutrition
}

\author{
Martin N. Mwangi ${ }^{1} \dagger$, Dennis G. A. B. Oonincx ${ }^{2} \dagger$, Tim Stouten ${ }^{2}$, Margot Veenenbos $^{2}$, \\ Alida Melse-Boonstra ${ }^{1}$, Marcel Dicke ${ }^{2}$ and Joop J. A. van Loon ${ }^{2 *}$ \\ ${ }^{1}$ Division of Human Nutrition, Wageningen University and Research, PO Box 17, 6700 AA Wageningen, The Netherlands \\ ${ }^{2}$ Laboratory of Entomology, Wageningen University and Research, PO Box 16, 6700 AA Wageningen, The Netherlands
}

\section{Abstract}

Dietary deficiencies in Fe and $\mathrm{Zn}$ are globally widespread, causing serious health problems such as anaemia, poor pregnancy outcomes, increased risk of morbidity and mortality, stunted growth and impaired physical and cognitive development. Edible insects, of which a diversity of over 2000 species is available, are dietary components for about 2 billion individuals and are a valuable source of animal protein. In the present paper, we review the available information on $\mathrm{Fe}$ and $\mathrm{Zn}$ in edible insects and their potential as a source of these micronutrients for the rapidly growing human population. The levels of Fe and $\mathrm{Zn}$ present in eleven edible insect species that are mass-reared and six species that are collected from nature are similar to or higher than in other animal-based food sources. High protein levels in edible insect species are associated with high $\mathrm{Fe}$ and $\mathrm{Zn}$ levels. Fe and Zn levels are significantly positively correlated. Biochemically, Fe and Zn in insects occur predominantly in non-haem forms, bound to the proteins ferritin, transferrin and other transport and storage proteins. Knowledge gaps exist for bioavailability in the human alimentary tract, the effect of anti-nutritional factors in other dietary components such as grains on Fe and Zn absorption and the effect of food preparation methods. We conclude that edible insects present unique opportunities for improving the micronutrient status of both resource-poor and Western populations.

Key words: Iron: Zinc: Insects: Anaemia: Bioavailability: Anti-nutritional factors: Food preparation methods

\section{Introduction}

Micronutrients, substances required in small amounts to sustain proper growth and development, enable the body to produce enzymes, hormones and other compounds essential for the maintenance of normal body functions. Micronutrient malnutrition affects over 2 billion individuals ${ }^{(1)}$. In terms of global public health significance, $\mathrm{Fe}, \mathrm{Zn}$, vitamin $\mathrm{A}$ and iodine are the most important micronutrients ${ }^{(2,3)}$. In the present review, we focus on $\mathrm{Fe}$ and $\mathrm{Zn}$ because: (a) both play a key role in preventing malnutrition and early stunting ${ }^{(3)}$; (b) deficiency of both is prevalent in areas of high cereal and low animal food consumption ${ }^{(4)}$; and (c) Fe and $\mathrm{Zn}$ from plant-based foods are generally poorly absorbed ${ }^{(4,5)}$.

Because Fe and Zn play important roles in numerous biochemical pathways, deficiency of these micronutrients has negative effects on many physiological systems including the gastrointestinal tract, the central nervous system, and the immune, skeletal and reproductive systems. These health effects in the long run result in a high economic burden for individuals and countries ${ }^{(6)}$. The WHO estimates that compared with the year 2000, the number of individuals who died from Fe-deficiency anaemia (IDA) in the year 2015 increased from 61000 to 78000 and thus, as a result, the crude death rate due to IDA increased from $1.0 \%$ to $1 \cdot 1 \%^{(7)}$. However, the Lancet series reported that there has been a significant reduction in the disability-adjusted life-years lost as a result of IDA $(-3 \cdot 3$ (95\% CI $-4 \cdot 8,-1 \cdot 8) \%)^{(8)}$. The WHO has called for integrated approaches to solving micronutrient deficiencies ${ }^{(2)}$.

Globally, over 2 billion individuals are anaemic, many due to Fe deficiency ${ }^{(1)}$. In resource-poor areas, the Fe-deficiency situation is exacerbated by infectious diseases such as malaria, hookworm infestation, HIV/AIDS, schistosomiasis and tuberculosis $^{(1)}$. The major health consequences of IDA include poor pregnancy outcome ${ }^{(9-11)}$, increased risk of morbidity and impaired physical and cognitive development ${ }^{(11)}$. It has been proposed that treating IDA can not only restore personal health but also raise national productivity levels by $20 \%{ }^{(1)}$.

The current WHO goal is to achieve a $50 \%$ reduction in the prevalence of anaemia in women of reproductive age by $2025^{(10,12)}$. The solutions to Fe deficiency and anaemia can be both inexpensive and effective. Usually, multifactorial and multisector approaches that are tailored to local conditions and that take into account the specific aetiology of anaemia are favoured by policy makers in view of their sustainability. The WHO has recommended dietary diversification, food fortification and Fe supplementation. The simultaneous control of infections and prevention of other nutritional deficiencies such as vitamin $\mathrm{B}_{12}$, folate, and vitamin $\mathrm{A}$ which are known to exacerbate Fe deficiency is also recommended.

Abbreviations: ANF, anti-nutritional factor; IDA, Fe-deficiency anaemia; LMIC, low- and middle-income countries.

* Corresponding author: Professor Dr J. J. A. van Loon, email joop.vanloon@wur.nl

$\dagger$ Contributed equally to the present review. 
Globally, $2 \cdot 2$ billion individuals are affected by $\mathrm{Zn}$ deficiency ${ }^{(13)}$. Recent estimates based on information from country food balance sheets indicate that, for $15-20 \%$ of the global population, the absorbable $\mathrm{Zn}$ content of national food supplies may be inadequate to meet $\mathrm{Zn}$ requirements ${ }^{(14)}$. $\mathrm{Zn}$ deficiency in humans is a result of reduced dietary intake, inadequate absorption, increased loss or increased use, for example in the case of disease. Manifestation of $\mathrm{Zn}$ deficiency includes increased prevalence of diarrhoea, pneumonia and malaria as a result of impaired immune function ${ }^{(15)}$. Furthermore, it is associated with impaired cognitive functions such as learning and hedonic tone ${ }^{(13,16)}$. Stunting (percentage of children under 5 years of age with height-for-age below the expected range of a reference population) is 'the best known measure of the adverse outcomes associated with zinc deficiency in populations, ${ }^{,(17)}$.

So far, little attention has been paid to insects as sources of Fe and $\mathrm{Zn}$ in the human diet. In the following we review the available information on $\mathrm{Fe}$ and $\mathrm{Zn}$ contents and the biochemical forms occurring in edible insects. Next we discuss bioavailability of Fe and $\mathrm{Zn}$ in relation to anti-nutritional factors (ANF) in food sources and outline future directions for research in this area.

\section{Iron and zinc concentrations in insects compared with livestock animals}

Analyses of both Fe and $\mathrm{Zn}$ concentrations in the same edible insect species showed $\mathrm{Fe}$ contents ranging between 4 and $62 \mathrm{mg} / 100 \mathrm{~g} \mathrm{DM}$ and $\mathrm{Zn}$ contents between 9 and $27 \mathrm{mg} / 100 \mathrm{~g}$ DM for eleven edible species that are mass-produced and six species that are collected from nature (Table 1). Fe content reported for the termite Macrotermes subbyalinus Rambur (Isoptera: Termitidae) is an outlier, causing the range for Fe contents to be wider than for Zn contents.

Comparing three commonly mass-reared insect species with common livestock species shows that the $\mathrm{Fe}$ and $\mathrm{Zn}$ concentrations in yellow mealworms, Tenebrio molitor L.
(Coleoptera: Tenebrionidae) are higher than for chicken and pork, but lower than for beef (Fig. 1). However, both African migratory locusts, Locusta migratoria L. (Orthoptera: Acrididae), and house crickets, Acheta domesticus L. (Orthoptera: Gryllidae), contain similar amounts of $\mathrm{Zn}$ and higher amounts of Fe, compared with chicken, pork and beef.

More detailed examination of the $\mathrm{Fe}, \mathrm{Zn}$ and crude protein contents of insects reveals significant correlations between $\mathrm{Fe}$ and $\mathrm{Zn}$ contents (Spearman's $\rho=0.592 ; P<0.001 ; n$ 48), and between $\mathrm{Fe}$ and $\mathrm{Zn}$ contents and body crude protein content (Spearman's $\rho=0.443 ; P=0.002 ; n$ 48; and $\rho=0.693 ; P<0.001$; $n 48$ for Fe and Zn, respectively; Fig. 2). Factors that contribute to differences in Fe and $\mathrm{Zn}$ concentrations are species (Table 1), developmental stage and diet ${ }^{(18)}$

\section{Species differences}

Yellow mealworm larvae have a lower Fe content $(3 \cdot 3-10 \cdot 0 \mathrm{mg} /$ $100 \mathrm{~g}$ DM) than African migratory locusts $(7 \cdot 8-21.7 \mathrm{mg} / 100 \mathrm{~g}$ $\mathrm{DM})^{(19-26)}$. Large variation in Fe content $(1 \cdot 0-75.0 \mathrm{mg} / 100 \mathrm{~g}$ $\mathrm{DM})$ has been reported for three species of termites belonging to the genus Macrotermes (Isoptera: Termitidae) ${ }^{(27-30)}$. Differences between species are not explained by taxonomic distance. For instance, adult yellow mealworms and morioworms (Zophobas morio Fabr.), both tenebrionid beetles, contain similar Fe concentrations ( $8.9 v .9 .2 \mathrm{mg} / 100 \mathrm{~g}$ DM), whereas their $\mathrm{Zn}$ concentrations differ $(14.4 v .8 .3 \mathrm{mg} / 100 \mathrm{~g} \mathrm{DM})^{(31)}$.

\section{Developmental stages}

Insects used as food are often consumed in a certain life stage, which is why few studies have reported on mineral concentrations in more than one life stage. Data on more than one life stage are available for the African migratory locust, adults of which have a higher Fe concentration compared with penultimate instars, whereas $\mathrm{Zn}$ content is similar for the two stages ${ }^{(21)}$. In house crickets Fe and Zn contents are similar for adults and nymphs ${ }^{(20)}$.

Table 1. Protein, iron and zinc content for a selection of insect species consumed by humans (Mean values and standard deviations where available)

\begin{tabular}{|c|c|c|c|c|c|c|c|c|}
\hline \multirow[b]{2}{*}{ Species* } & \multirow[b]{2}{*}{ Scientific name } & \multicolumn{2}{|c|}{ Crude protein (\% DM) } & \multicolumn{2}{|c|}{$\mathrm{Fe}(\mathrm{mg} / 100 \mathrm{~g} \mathrm{DM})$} & \multicolumn{2}{|c|}{$\mathrm{Zn}(\mathrm{mg} / 100 \mathrm{~g} \mathrm{DM})$} & \multirow[b]{2}{*}{ References } \\
\hline & & Mean & SD & Mean & SD & Mean & SD & \\
\hline House cricket & Acheta domesticus & 62.9 & 4.56 & $9 \cdot 1$ & 4.47 & $19 \cdot 9$ & 3.02 & $(19,20,23,25,26,82)$ \\
\hline Jamaican field cricket & Gryllus assimilis & $51 \cdot 25$ & & $17 \cdot 93$ & & $15 \cdot 57$ & & $(26)$ \\
\hline Two-spotted cricket & Gryllus bimaculatus & $58 \cdot 32$ & & 9.66 & & $22 \cdot 43$ & & (24) \\
\hline Tropical house cricket & Gryllodes sigillatus & $70 \cdot 00$ & & $4 \cdot 23$ & & $13 \cdot 9$ & & (22) \\
\hline Migratory locust & Locusta migratoria & $59 \cdot 0$ & $3 \cdot 11$ & $13 \cdot 7$ & $4 \cdot 35$ & $14 \cdot 8$ & 1.09 & (21) \\
\hline Desert locust & Schistocerca gregaria & 76 & & $8 \cdot 38$ & & $18 \cdot 6$ & & (22) \\
\hline Lesser mealworm & Alphitobius diaperinus & $67 \cdot 85$ & & $21 \cdot 80$ & & $26 \cdot 80$ & & (83) \\
\hline Yellow mealworm & Tenebrio molitor & $51 \cdot 7$ & 4.80 & $5 \cdot 3$ & $2 \cdot 16$ & $11 \cdot 8$ & 1.60 & $(19,20,22-26)$ \\
\hline Superworm & Zophobas morio & $42 \cdot 9$ & $3 \cdot 22$ & 3.8 & 1.00 & $7 \cdot 7$ & 0.77 & $(19,20,25)$ \\
\hline Silkworm & Bombyx mori & $51 \cdot 8$ & $2 \cdot 23$ & $15 \cdot 9$ & $7 \cdot 23$ & $16 \cdot 8$ & 5.55 & $(20,84,85)$ \\
\hline Waxworm & Galleria mellonella & 39.5 & $4 \cdot 78$ & $5 \cdot 0$ & 1.75 & $8 \cdot 6$ & 3.36 & $(19,20,23,25,86)$ \\
\hline Termite & Macrotermes subhyalinus & $38 \cdot 8$ & 0.57 & 61.9 & $8 \cdot 61$ & $9 \cdot 5$ & 1.43 & $(29,87)$ \\
\hline Arboreal termite & Nasutitermes spp. & $48 \cdot 8$ & & $24 \cdot 6$ & & $18 \cdot 4$ & & (88) \\
\hline Palm worm & Rhynchophorus palmarum & $28 \cdot 0$ & $9 \cdot 26$ & $5 \cdot 1$ & $1 \cdot 25$ & $12 \cdot 9$ & 1.39 & (89) \\
\hline Sago grub & Rhynchophorus ferrugineus & $34 \cdot 1$ & 1.48 & $9 \cdot 0$ & 0.55 & $9 \cdot 5$ & $4 \cdot 26$ & $(90)$ \\
\hline Longhorn grasshopper & Ruspolia differens & $43 \cdot 7$ & 0.60 & $14 \cdot 8$ & 1.80 & 14.9 & $2 \cdot 45$ & (30) \\
\hline Cornfield grasshopper & Sphenarium purpurascens & $65 \cdot 2$ & & 18 & & 42 & & $(91)$ \\
\hline
\end{tabular}

* The first eleven species are globally mass-reared; the last six species are collected from nature. 

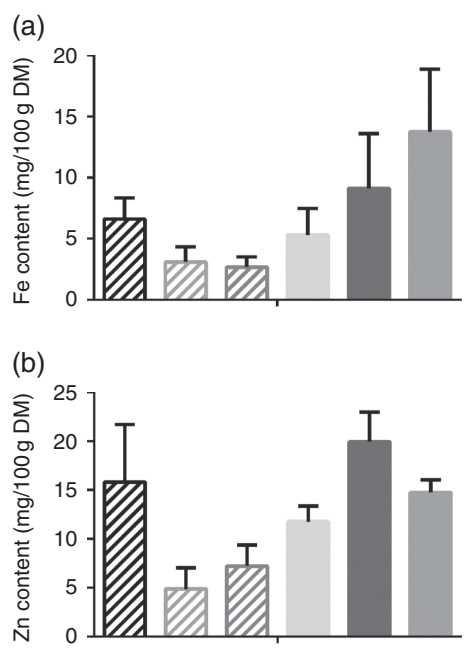

Fig. 1. Iron (a) and zinc (b) content on a DM basis in meat from conventional

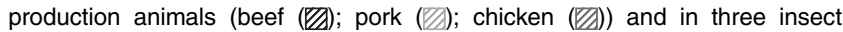
species (yellow mealworm Tenebrio molitor L. $(\square$ ), house cricket Acheta domesticus L. ( $\square$ ) and African migratory locust Locusta migratoria L. ( $\square$ )). Data for conventional meat were adapted from the US Department of Agriculture (USDA) food database (USDA National Nutrient Database for Standard Reference, release 28; Agricultural Research Service, USDA, Nutrient Data Laboratory; http://www.ars.usda.gov/nea/bhnrc/ndl, selecting data on meat only (excluding pure fat and organs)) reporting both iron and zinc concentrations. Insect data were adapted from references ${ }^{(19,20,21,22,25)}$. Values are means, with standard deviations represented by vertical bars.

The same is true for yellow mealworms; data from several studies suggest similar concentrations of $\mathrm{Fe}(3 \cdot 3-10 \cdot 0 v \cdot 3 \cdot 7-8.9 \mathrm{mg} /$ $100 \mathrm{~g} \mathrm{DM})$ and $\mathrm{Zn}(9 \cdot 5-13.7$ v. $11 \cdot 3-14.4 \mathrm{mg} / 100 \mathrm{~g} \mathrm{DM})$ for larvae and adults, respectively $(19,20,22,24-26,31)$

\section{Dietary effects}

In general, the chemical composition of insects is affected by the diet they consume $e^{(21,32,33)}$. Micronutrient contents are regulated in order to maintain body homeostasis and prevent toxic concentrations. For instance, the Jamaican field cricket (Gryllus assimilis Fabr.; Orthoptera: Gryllidae) decreases Zn assimilation and increases $\mathrm{Zn}$ excretion when provided with higher dietary $\mathrm{Zn}$ concentrations, such that a sixteen-fold increase in dietary $\mathrm{Zn}$ resulted in a twofold increase in $\mathrm{Zn}$ content in this cricket $^{(34)}$. Hence, $\mathrm{Zn}$ levels seem to depend on dietary composition.

\section{Biochemical forms of iron and zinc in insects}

As for humans, dietary $\mathrm{Fe}$ and $\mathrm{Zn}$ are essential for proper physiological functioning of insects, fulfilling roles in DNA synthesis, oxidation, cuticle biosynthesis and acting as a cofactor in a variety of enzymes ${ }^{(35,36)}$. Transferrin and ferritin are two major proteins involved in Fe metabolism in insects, both having multiple functions. Transferrin is an Fe transporter, it might act as an antibiotic agent and it can be a vitellogenic protein $^{(37)}$. Ferritin functions in Fe transport and storage and is present in the endoplasmatic reticulum, nuclear envelope and mitochondria of gut and fat body cells in particular, and extracellularly in the haemolymph ${ }^{(38,39)}$. Multiple studies investigating the transport mechanisms of $\mathrm{Zn}$ in insects have focused on

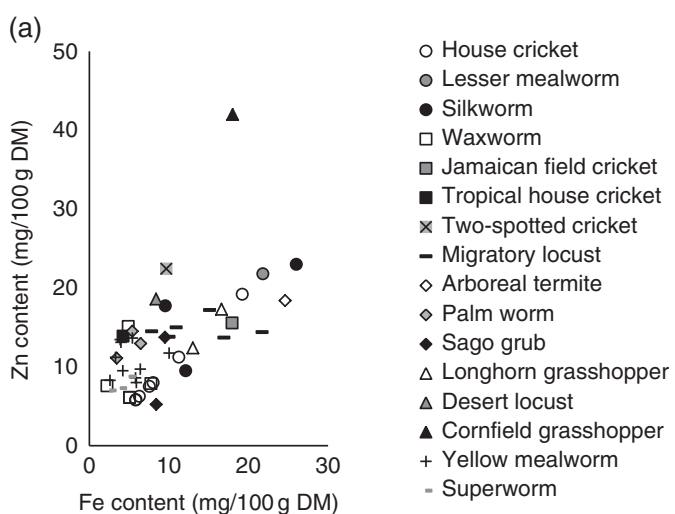

(b)
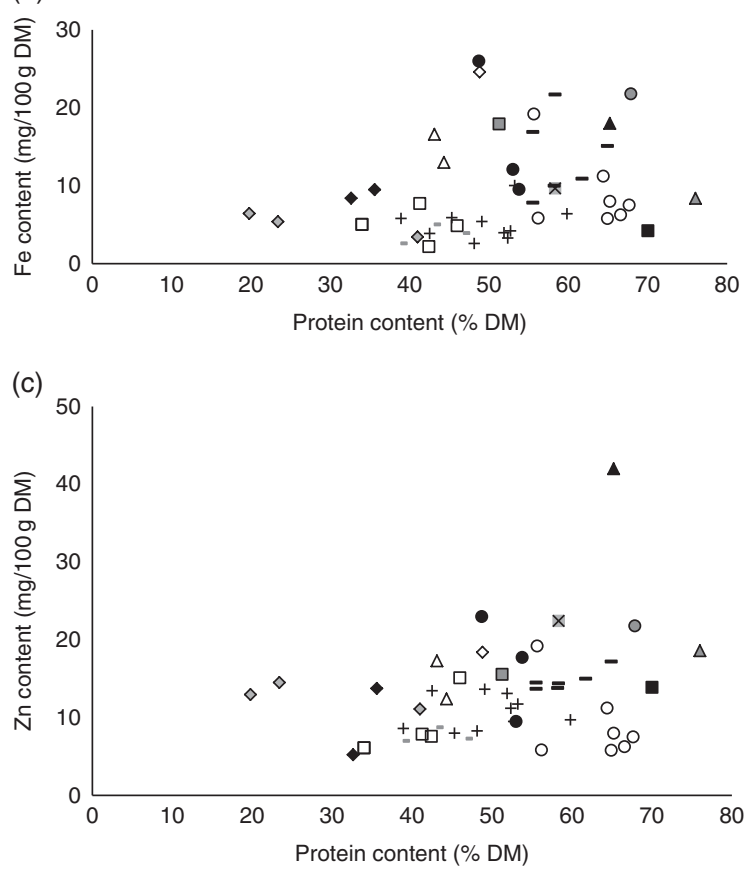

Fig. 2. Scatter plots of iron content, zinc content (both expressed as $\mathrm{mg} / 100 \mathrm{~g}$ DM) and crude protein content (\% DM) of sixteen of the seventeen insect species listed in Table 1. Data for Macrotermes subhyalinus were considered outliers and have been excluded. (a) Iron content (mg/100 g DM) plotted against zinc content (mg/100 g DM) (Spearman's $\rho=0.592 ; P<0.001 ; n$ 48). (b) Iron content plotted against crude protein content (Spearman's $\rho=0.443$; $P=0.002 ; n$ 48). (c) Zinc content plotted against crude protein content $(\rho=0.693 ; P<0.001 ; n$ 48).

Zn transporters in the model species Drosophila melanogaster. Thus far, two families of $\mathrm{Zn}$ transporters have been identified, ten $\mathrm{dZip}$ and seven $\mathrm{dZnT}$ proteins ${ }^{(40)}$. These transporters are homologues to the human Zip (SLC39) and ZnT (SLC30) family members and are responsible for cellular influx and efflux, respectively. $\mathrm{Zn}$ transporters can be found ubiquitously or accumulated in specific organs/regions of the gastrointestinal tract, for example, the expression of dZip1 in the midgut and dZnT35C in the Malpighian tubules of D. melanogaster ${ }^{(40-42)}$ that have roles in the absorption and excretion of $\mathrm{Zn}$. Much less information is available on $\mathrm{Zn}$ storage in insects. $\mathrm{Zn}$ is present throughout the gastrointestinal tract of $D$. melanogaster with accumulation regions in the posterior midgut, the crop and the Malpighian tubules ${ }^{(43)}$. As most information on the physiological 
functions of $\mathrm{Fe}$ and $\mathrm{Zn}$ in insects stems from research on D. melanogaster, it remains to be investigated whether the information is representative for the edible insect species which are the focus of the present review. Some differences in $\mathrm{Fe}$ metabolism between different insect orders have been demonstrated, showing different allocations of ferritin in midgut cells ${ }^{(39)}$.

\section{Bioavailability of iron and zinc in insect-derived food}

Nutrient bioavailability refers to the proportion of a nutrient that is absorbed from the diet and used for normal body functions ${ }^{(44,45)}$ and is governed by host-related and food-related factors such as the food matrix and the chemical form of the nutrient in question. Internal factors may include age, sex, nutrient status and life stage (for example, pregnancy). Nutrient bioavailability depends on different processes, including release of the nutrient from the physico-chemical food matrix; effects of digestive enzymes in the intestine; binding and uptake by the intestinal mucosa; transfer across the gut wall to the blood or lymphatic circulation; systemic distribution; systemic deposition; metabolic and functional use; and excretion via urine or faeces ${ }^{(45)}$.

In vertebrates, Fe is usually found in muscles in the form of myoglobin and $\mathrm{Hb}$. However, the primary form of haem-Fe in insects is found in cytochromes. It is presumed that the bioavailability of cytochrome haem-Fe is similar to that of myoglobin and $\mathrm{Hb}^{(35)}$. Fe in insects is predominantly present as the non-haem molecules ferritin and holoferritin. Because ferritin functions as a storage protein for $\mathrm{Fe}$, each molecule is capable of containing thousands of $\mathrm{Fe}$ atoms, typically in the ferrous state, which increases their bioavailability. Insect ferritin has not yet been well characterised, although it is known to differ from the ferritin found in vertebrates ${ }^{(39)}$. Phyto-ferritin, present in legumes such as soya, appears to be better bioavailable than $\mathrm{Fe}$ in the form of reduced salts ${ }^{(46-51)}$. This is explained by protection of Fe from ANF, such as phytates, oxalates and tannins, by the protein complex. Although much of the diet-derived ferritin may not reach the intestinal absorption site intact, due to destruction during cooking and gastric digestion ${ }^{(52)}$, the suggestion of a separate transporter for phyto-ferritin in human cells indicates that there is an absorption potential ${ }^{(53)}$. Even if only a small fraction of the original amount reaches the absorption site, it can have a tremendous impact due to the large number of $\mathrm{Fe}$ atoms present in ferritin proteins.

Bioaccessibility (in vitro solubility or dialysability of a nutrient) ${ }^{(54)}$ of micronutrients present in various species of edible insects has not been widely studied but is expected to follow trends of meat, fish and poultry. However, the non-haem-Fe present in most edible insects may be poorly soluble under intestinal conditions and may also be affected by other components of the diet ${ }^{(44)}$. Furthermore, the impact of known enhancers and inhibitors of nutrient bioavailability on (micro)nutrients present in edible insects is not known. Examples of nutrient enhancers include the "meat factor' present in meat, fish and poultry thought to be a result of muscle protein, which enhances absorption of Fe from all foods ${ }^{(44)}$. Protein (more specifically: amino acids such as histidine and methionine) is known to enhance non-haem-Fe and $\mathrm{Zn}$ absorption $^{(44,55)}$; therefore, insects with a high protein content might promote the uptake of these minerals.
Recently, the in vitro solubility and availability of Fe and $\mathrm{Zn}$ from various insect species (grasshopper, cricket, mealworms and buffalo worms) have been compared with those from sirloin beef using a Caco- 2 cell model. It was found that Fe and $\mathrm{Zn}$ solubility was significantly higher from the insect samples than from beef, but bioaccessibility of Fe (measured as the ferritin concentration in Caco-2 cells) was more diverse, with the highest response for buffalo worms (Alphitobius diaperinus Panzer; Coleoptera: Tenebrionidae), followed by beef, yellow mealworms, cornfield grasshoppers (Sphenarium purpurascens Charp.; Orthoptera: Pyrgomorphidae), and two-spotted crickets (Gryllus bimaculatus Geer; Orthoptera: Gryllidae) ${ }^{(56)}$. In the same study by Latunde-Dada et al. ${ }^{(56)}$, it was shown that the addition of insects to wheat flour (1:1) was superior to beef in increasing $\mathrm{Fe}$ and $\mathrm{Zn}$ solubility in the composite mixtures.

Based on the above, it is likely that the addition of insects to current starch-based diets, exemplary for individuals living in many low- and middle-income countries (LMIC), will provide additional Fe and $\mathrm{Zn}$, that could potentially fill the requirement gap, and maybe increase the bioavailability of native and fortification $\mathrm{Fe}$ in the starchy foods. As an example, a complementary feeding cereal enriched with locally derived dried caterpillars showed a small increment in $\mathrm{Hb}$ concentrations in infants and children in the DRC Congo ${ }^{(57)}$. A better understanding of the bioavailability of Fe and $\mathrm{Zn}$ from insects may help to improve the design of such a strategy. In addition, good bioavailability of $\mathrm{Fe}$ and $\mathrm{Zn}$ will also mean that insects are a valuable food item for consumers in other parts of the world, including Europe and North America.

\section{Anti-nutritional factors}

ANF are compounds that interfere with the absorption of one or more nutrients from human food, animal feed or water ${ }^{(58)}$. Diets laden with ANF such as phytic acid can cause micronutrient malnutrition by reducing the bioavailability of micronutrients such as Fe and $\mathrm{Zn}$. In many LMIC, micronutrient malnutrition is further exacerbated by the consumption of monotonous staple food-based diets which contain enough energy to ease hunger pangs but not enough micronutrients. In addition, the staple foods are usually high in ANF.

An important ANF reducing Fe and $\mathrm{Zn}$ absorption is phytic acid, which is the storage form of $\mathrm{P}$ in grains, nuts and legumes. When chelated to a mineral in the seed, phytic acid is known as phytate. Phytic acid is highly abundant in some plant foods (wholegrain cereals, pulses, seeds, nuts) and it binds minerals such as $\mathrm{Fe}, \mathrm{Zn}$ and $\mathrm{Ca}$, thereby decreasing their bioavailability $^{(59)}$. This is because it forms soluble or insoluble complexes that cannot be absorbed ${ }^{(60)}$. Similarly, other inhibitors of nutrient absorption may bind the nutrient, render the nutrient insoluble, or compete for the same uptake system. The latter has been observed in the interaction between $\mathrm{Ca}$ and nonhaem-Fe, especially when $\mathrm{Ca}$ and/or Fe supplements are used outside the meal setting ${ }^{(61)}$.

Phytic acid content varies greatly among plants due to the type/ species of seed, environmental condition, climate and soil quality ${ }^{(59)}$. In grains, phytic acid is primarily found in the bran while in legumes it is found in the cotyledon layer ${ }^{(59)}$. With the exception 
of phytic acid, the extent to which other ANF such as polyphenols and tannins affect the bioavailability of $\mathrm{Fe}$ and $\mathrm{Zn}$ in humans is not clearly established. Management and control of dietary inhibitors and enhancers is critical. For example, the bioavailability of non-haem-Fe, such as that found in plant foods, eggs and milk, is inhibited by phytates but may be enhanced by vitamin C. Practical ways to reduce dietary inhibitors and increase Fe absorption also include fermentation, germination, malting and adopting food fortification practices, i.e. dietary modification strategies to either include in a meal foods that can promote the absorption of a micronutrient or to exclude foods that inhibit its absorption. Whether $\mathrm{Zn}$ and the biochemical form of Fe present in edible insects are affected by ANF is a critical consideration worth further research because cereal-based staple foods are consumed in the same meal as the insects.

Nutrient bioavailability also responds to systemic factors such as deficiency of a nutrient or changes in the physiological state, for example during pregnancy ${ }^{(61)}$. This may result in the upregulation or down-regulation of the absorption of a nutrient. Similarly, infections and inflammation may reduce the absorptive capacity of the gut ${ }^{(62)}$. It is important to know the bioavailability of nutrients such as $\mathrm{Fe}, \mathrm{Zn}$, folate, $\mathrm{Ca}, \mathrm{Mg}$ and vitamin $\mathrm{A}$ in order to translate their physiological requirements into actual dietary requirements ${ }^{(61)}$.

\section{Effect of food preparation methods on the mineral content of edible insects}

The nutrient quality of different foods can be altered by different methods of food processing such as frying and boiling ${ }^{(63)}$. Cooking loss of minerals may be caused by the outflow of minerals from the food materials ${ }^{(64)}$. These losses can be prevented by various methods such as: (a) eating the boiled food with the soup made using the water/stock of the boiled food; (b) boiling in salted water (up to about $1 \% \mathrm{NaCl}$ ); (c) avoidance of too long boiling; and (d) using cooking methods that cause a lesser amount of mineral losses, for example, stewing, frying or parching ${ }^{(64)}$. Most insects are either sautéed, baked, ground into a paste before addition to foods, stewed, boiled or fried. Numerous websites offer recipes for cooking insects ${ }^{(65)}$. As is the norm for any food product, consumer education aimed at the retention of nutrients from edible insects before, during and after cooking must be systematically introduced alongside the insect products. So far, the effect of various food preparation methods on the micronutrient/ mineral content of various insect sources has not been fully investigated.

\section{Conclusions and implications}

The relative contribution of diets rich in edible insects towards solving micronutrient malnutrition needs to be quantified. Preliminary findings suggest that Fe biofortification of staple food crops can be efficacious for improving $\mathrm{Fe}$ status ${ }^{(66-69)}$. Furthermore, although the inclusion of animal foods in the diet can be a good strategy to combat micronutrient malnutrition, this is often not affordable for the individuals suffering from micronutrient malnutrition and thus often is an unsuitable option. The Lancet series on interventions for improvement of maternal and child nutrition identified the need for innovative community-based strategies for scaling up the coverage of nutrition interventions that have the potential to reach especially the poor populations ${ }^{(3)}$.

The information on Fe and $\mathrm{Zn}$ contents in edible insects is at present still limited and best documented for the species discussed in the present paper which feature in human diets around the world ${ }^{(70)}$ and which are also good sources of protein, fat and dietary fibre ${ }^{(18)}$. Consumption of edible insects is widely practised in parts of Africa, Asia and Latin America. Current estimates are that insects form part of the diet of about 2 billion individuals, in particular in tropical areas of the world $^{(71)}$. Therefore, insects are receiving increasing attention for their potential to alleviate the projected protein shortage by $2050^{(71,72)}$

Although the consumption of edible insects has been shown to contribute to protein intake ${ }^{(73-77)}$, the contribution of edible insects to the micronutrient pool has not been explored. We postulate that the addition of edible insects to the human diet, either whole, in-part, or processed, will greatly contribute towards the achievement of the 'zero hunger' sustainable development goal target, especially because the large majority of the hungry individuals (98\% of 795 million individuals) who also suffer from hidden hunger live in $\mathrm{LMIC}^{(78)}$ where edible insects are widely accepted.

The global human population is growing rapidly and is expected to reach 9-10 billion individuals by 2050 . At present, $70 \%$ of the global agricultural land is used to produce livestock that provide meat and dairy products as favoured protein sources $^{(71)}$. Increasing the production of livestock is seriously constrained by the availability of agricultural land and will aggravate climate change ${ }^{(79)}$. Insect production requires much less agricultural land per unit protein produced and contributes much less to climate change than livestock ${ }^{(80)}$.

Regarding bioavailability of $\mathrm{Fe}$ and $\mathrm{Zn}$ from insect-derived food, only data from an in vitro experiment are available. Although the results are promising, in vivo studies on human subjects are required to quantify the absorption efficiency of Fe and $\mathrm{Zn}$ from insect-containing foods. Insects are receiving increased attention primarily due to their high protein content which is favourable for enhancing the uptake of Fe and $\mathrm{Zn}$. Factors that may interfere with $\mathrm{Fe}$ and $\mathrm{Zn}$ absorption from insects such as processing, preservation, preparation and combinations with other foods need to be addressed in controlled studies to allow full utilisation of the potential of insects as Fe and $\mathrm{Zn}$ sources in human $\operatorname{diets}^{(81)}$.

\section{Acknowledgements}

The present review was funded by the Wellcome Trust (grant no. $106856 / \mathrm{Z} / 15 / \mathrm{Z}$ ). The Wellcome Trust had no role in the design, analysis or writing of this article.

All authors contributed to discussions and had input into collecting data from literature and writing the article. J. J. A. v. L. was responsible for producing the final version of the article.

There are no conflicts of interest. 


\section{References}

1. World Health Organization (2016) Micronutrient deficiencies. http://www.who.int/nutrition/topics/ida/en/ (accessed November 2017).

2. World Health Organization (2016) Micronutrients. http:// www.who.int/nutrition/topics/micronutrients/en/ (accessed November 2017).

3. Bhutta ZA, Das JK, Rizvi A, et al. (2013) Evidence-based interventions for improvement of maternal and child nutrition: what can be done and at what cost? Lancet 382, 452-477.

4. Roohani N, Hurrell R, Kelishadi R, et al. (2013) Zinc and its importance for human health: an integrative review. J Res Med Sci 18, 144-157.

5. Kumar R (1992) Anti-nutritional factors, the potential risks of toxicity and methods to alleviate them. In Legume Trees and Other Fodder Trees as Protein Sources for Livestock, pp 145160 [A Speedy and P Pugliese, editors]. Rome: FAO.

6. Wieser S, Plessow R, Eichler K, et al. (2013) Burden of micronutrient deficiencies by socio-economic strata in children aged 6 months to 5 years in the Philippines. BMC Public Health 13, 1167.

7. World Health Organization (2016) Global health estimates 2015: Deaths by cause, age, sex and country, 2000-2015. http:// www.who.int/healthinfo/global_burden_disease/estimates/en/ index1.html (accessed May 2018).

8. Kassebaum NJ, Arora M, Barber RM, et al. (2016) Global, regional, and national disability-adjusted life-years (DALYs) for 315 diseases and injuries and healthy life expectancy (HALE), 1990-2015: a systematic analysis for the Global Burden of Disease Study 2015. Lancet 388, 1603-1658.

9. Mwangi MN, Roth JM, Smit MR, et al. (2015) Effect of daily antenatal iron supplementation on Plasmodium infection in Kenyan women: a randomized clinical trial. JAMA 314, 1009-1020.

10. International Food Policy Research Institute (2016) Global Nutrition Report 2016: From Promise to Impact: Ending Malnutrition by 2030. Washington, DC: International Food Policy Research Institute.

11. Longo DL \& Camaschella C (2015) Iron-deficiency anemia. $N$ Engl J Med 372, 1832-1843.

12. World Health Organization (2015) Global targets 2025 to improve maternal, infant and young child nutrition. http:// www.who.int/nutrition/topics/nutrition_globaltargets2025/en (accessed November 2017).

13. Prasad AS (2012) Discovery of human zinc deficiency: 50 years later. J Trace Elem Med Biol 26, 66-69.

14. Wessells KR, Singh GM \& Brown KH (2012) Estimating the global prevalence of inadequate zinc intake from national food balance sheets: effects of methodological assumptions. PLOS ONE 7, e50565.

15. Kumar P \& Clark ML (2009) Clark's Clinical Medicine. Edinburgh: Saunders Elsevier.

16. Takeda A (2000) Movement of zinc and its functional significance in the brain. Brain Res Rev 34, 137-148.

17. International Zinc Nutrition Consultative Group (2007) Quantifying the risk of zinc deficiency: recommended indicators. IZiNCG Technical Brief no. 1. http://www.a2zproject.org/pdf/ English_brief1.pdf (accessed May 2018).

18. Finke MD \& Oonincx DGAB (2013) Insects as food for insectivores. In Mass Production of Beneficial Organisms: Invertebrates and Entomopathogens, pp. 583-616 [JA MoralesRamos, M Guadalupe Rojas and DI Shapiro-Ilanm, editors]. London, Waltham, MA and San Diego, CA: Academic Press.

19. Barker D, Fitzpatrick MP \& Dierenfeld ES (1998) Nutrient composition of selected whole invertebrates. Zoo Biol 17, $123-134$.
20. Finke MD (2002) Complete nutrient composition of commercially raised invertebrates used as food for insectivores. ZOO Biol 21, 269-285.

21. Oonincx DGAB \& Van der Poel AFB (2011) Effects of diet on the chemical composition of migratory locusts (Locusta migratoria). Zoo Biol 30, 9-16.

22. Zielińska E, Baraniak B, Karaś M, et al. (2015) Selected species of edible insects as a source of nutrient composition. Food Res Int 77, 460-466.

23. Bernard JB \& Allen ME (1997) Feeding captive insectivorous animals: nutritional aspects of insects as food. Nutrition Advisory Group Handbook, August 1997, fact sheet 3, pp. 1-7.

24. Ghosh S, Lee SM, Jung C, et al. (2017) Nutritional composition of five commercial edible insects in South Korea. $J$ Asia-Pac Entomol 20, 686-694.

25. Finke MD (2015) Complete nutrient content of four species of commercially available feeder insects fed enhanced diets during growth. Zoo Biol 34, 554-564.

26. Punzo F (2003) Nutrient composition of some insects and arachnids. Fla Sci 66, 84-98.

27. Banjo AD, Lawal OA \& Songonuga EA (2006) The nutritional value of fourteen species of edible insects in southwestern Nigeria. Afr J Biotechnol 5, 298-301.

28. Igwe CU, Ujowundu CO, Nwaogu LA, et al. (2011) Chemical analysis of an edible African termite Macrotermes nigeriensis, a potential antidote to food security problem. Biochem Anal Biochem 1, 1000105.

29. Niaba KP, Gbogouri GA \& Gnakri D (2011) Potentialités nutritionnelles du reproducteur ailé du termite Macrotermes subhyalinus capturé à Abobo-doumé, Côte d'Ivoire (Nutritional potential of the winged breeder of the termite Macrotermes subhyalinus captured in Abobo-doumé, Ivory Coast). J Appl Biosci 40, 2706-2714.

30. Kinyuru JN, Kenji GM \& Muhoho SN (2010) Nutritional potential of Longhorn grasshopper (Ruspolia differens) consumed in Siaya district, Kenya. J Agr Sci Tech 12, 32-46.

31. Oonincx DGAB \& Dierenfeld ES (2012) An investigation into the chemical composition of alternative invertebrate prey. Zoo Biol 31, 40-54.

32. Oonincx DGAB, Van Broekhoven S, Van Huis A, et al. (2015) Feed conversion, survival and development, and composition of four insect species on diets composed of food by-products. PLOS ONE 10, e0144601.

33. Van Broekhoven S, Oonincx DGAB, Van Huis A, et al. (2015) Growth performance and feed conversion efficiency of three edible mealworm species (Coleoptera: Tenebrionidae) on diets composed of organic by-products. J Insect Physiol $\mathbf{7 3}$, $1-10$.

34. Bednarska AJ, Opyd M, Żurawicz E, et al. (2015) Regulation of body metal concentrations: toxicokinetics of cadmium and zinc in crickets. Ecotox Envir Saf 119, 9-14.

35. Locke M \& Nichol H (1992) Iron economy in insects: transport, metabolism, and storage. Ann Rev Entomol 37, $195-215$.

36. Vallee BL \& Falchuk KH (1993) The biochemical basis of zinc physiology. Physiol Rev 73, 79-118.

37. Nichol H, Law JH \& Winzerling JJ (2002) Iron metabolism in insects. Ann Rev Entomol 47, 535-559.

38. Pham DQD \& Winzerling JJ (2010) Insect ferritins: typical or atypical? Biochim Biophys Acta 1800, 824-833.

39. Nichol H \& Locke M (1990) The localization of ferritin in insects. Tissue Cell 22, 767-777.

40. Lye JC, Richards CD, Dechen K, et al. (2012) Systematic functional characterization of putative zinc transport genes and identification of zinc toxicosis phenotypes in Drosophila melanogaster. J Exp Biol 215, 3254-3265. 
41. Yepiskoposyan H, Egli D, Fergestad T, et al. (2006) Transcriptome response to heavy metal stress in Drosophila reveals a new zinc transporter that confers resistance to zinc. Nucl Acids Res 34, 4866-4877.

42. Qin Q, Wang X \& Zhou B (2013) Functional studies of Drosophila zinc transporters reveal the mechanism for dietary zinc absorption and regulation. BMC Biol 11, 101.

43. Jones MWM, de Jonge MD, James SA, et al. (2015) Elemental mapping of the entire intact Drosophila gastrointestinal tract. J Biol Inorg Chem 20, 979-987.

44. Hurrell R \& Egli I (2010) Iron bioavailability and dietary reference values. Am J Clin Nutr 91, 1461S-1467S

45. Aggett PJ (2010) Population reference intakes and micronutrient bioavailability: a European perspective. Am J Clin Nutr 91, 1433S-1437S.

46. Beard JL, Dawson H \& Piñero DJ (1996) Iron metabolism: a comprehensive review. Nutr Rev 54, 295-317.

47. Murray-Kolb LE, Welch R, Theil EC, et al. (2003) Women with low iron stores absorb iron from soybeans. Am J Clin Nutr 77, 180-184.

48. Layrisse M, MartInez-Torres C, Renzy M, et al. (1975) Ferritin iron absorption in man. Blood 45, 689-698.

49. Lynch SR, Beard JL, Dassenko SA, et al. (1984) Iron absorption from legumes in humans. Am J Clin Nutr 40, 42-47.

50. Sayers MH, Lynch SR, Jacobs P, et al. (1973) The effects of ascorbic acid supplementation on the absorption of iron in maize, wheat and soya. Br J Haematol 24, 209-218.

51. Lönnerdal B, Bryant A, Liu X, et al. (2006) Iron absorption from soybean ferritin in nonanemic women. Am J Clin Nutr 83, 103-107.

52. Hoppler M, Schönbächler A, Meile L, et al. (2008) Ferritin-iron is released during boiling and in vitro gastric digestion. J Nutr 138, 878-884.

53. San Martin CD, Garri C, Pizarro F, et al. (2008) Caco-2 intestinal epithelial cells absorb soybean ferritin by $\mu_{2}$ subunit (AP2)-dependent endocytosis. J Nutr 138, 659-666.

54. Holst B \& Williamson G (2008) Nutrients and phytochemicals: from bioavailability to bioefficacy beyond antioxidants. Curr Opin Biotechnol 19, 73-82.

55. Lönnerdal BO (2000) Dietary factors influencing zinc absorption. J Nutr 130, 1378S-1383S

56. Latunde-Dada GO, Yang W \& Vera Aviles M (2016) In vitro iron availability from insects and sirloin beef. J Agric Food Chem 64, 8420-8424.

57. Bauserman M, Lokangaka A, Gado J, et al. (2015) A clusterrandomized trial determining the efficacy of caterpillar cereal as a locally available and sustainable complementary food to prevent stunting and anaemia. Public Health Nutr 18, 1785-1792.

58. Atwood T, Cammack R, Atwood T, et al. (2006) Oxford Dictionary of Biochemistry and Molecular Biology. Oxford: Oxford University Press.

59. Schlemmer U, Frølich W, Prieto RM, et al. (2009) Phytate in foods and significance for humans: food sources, intake, processing, bioavailability, protective role and analysis. Mol Nutr Food Res 53, 330-375.

60. Zhou JR \& Erdman JW Jr (1995) Phytic acid in health and disease. Crit Rev Food Sci Nutri 35, 495-508.

61. Gibson RS (2007) The role of diet- and host-related factors in nutrient bioavailability and thus in nutrient-based dietary requirement estimates. Food Nutr Bull 28, S77-S100.

62. Lynch SR (2007) Influence of infection/inflammation, thalassemia and nutritional status on iron absorption. Int J Vitam Nutr Res 77, 217-223.

63. Severi S, Bedogni G, Manzieri AM, et al. (1997) Effects of cooking and storage methods on the micronutrient content of foods. Eur J Cancer Prev 6, S21-S24.
64. Kimura M \& Itokawa Y (1990) Cooking losses of minerals in foods and its nutritional significance. J Nutr Sci Vitaminol 36, S25-S33.

65. Oaklander M (2015) Delicious bug recipes from chefs. http://time.com/3830167/eating-bugs-insects-recipes/ (accessed November 2017).

66. De Moura FF, Palmer AC, Finkelstein JL, et al. (2014) Are biofortified staple food crops improving vitamin A and iron status in women and children? New evidence from efficacy trials. Adv Nutr 5, 568-570.

67. Bouis HE \& Saltzman A (2017) Improving nutrition through biofortification: a review of evidence from HarvestPlus, 2003 through 2016. Glob Food Sec 12, 49-58.

68. Haas JD, Luna SV, Lung'aho MG, et al. (2016) Consuming iron biofortified beans increases iron status in Rwandan women after 128 days in a randomized controlled feeding trial. $J$ Nutr 146, 1586-1592.

69. King JC, Brown KH, Gibson RS, et al. (2016) Biomarkers of Nutrition for Development (BOND) - zinc review. J Nutr 146, 858S-885S.

70. Jongema Y (2012) List of edible insect species of the world. Wageningen, Laboratory of Entomology, Wageningen University. http://www.wur.nl/en/Expertise-Services/Chair-groups/PlantSciences/Laboratory-of-Entomology/Edible-insects/Worldwidespecies-list.htm, accessed July 2017.

71. Van Huis A, Van Itterbeeck J, Klunder H, et al. (2013) Edible Insects: Future Prospects for Food and Feed Security, FAO Forestry Paper no. 171]. Rome: FAO.

72. Van Huis A (2013) Potential of insects as food and feed in assuring food security. Ann Rev Entomol 58, 563-583.

73. Lizot J (1977) Population, resources and warfare among the Yanomami. Man 12, 497-517.

74. Dufour DL (1987) Insects as food: a case study from the northwest Amazon. Am Anthropol 89, 383-397.

75. Paoletti MG \& Dreon AL (2005) Minilivestock, environment, sustainability, and local knowledge disappearance. In Ecological Implications of Minilivestock: Potential of Insects, Rodents, Frogs, and Snails, pp. 1-18 [MG Paoletti, editor]. Enfield, NH: Science Publishers Inc.

76. Raubenheimer D \& Rothman JM (2013) Nutritional ecology of entomophagy in humans and other primates. Annu Rev Entomol 58, 141-160.

77. Kitsa K (1989) Contribution des insectes comestibles à l'amélioration de la ration alimentaire au Kasaï-Occidental (Contribution of edible insects to the improvement of food rations in Kasaï-Occidental). Zaïre-Afrique 29, 511-519.

78. Food and Agriculture Organization on the United Nations (2015) ) The State of Food Insecurity in the World: Meeting the 2015 International Hunger Targets: Taking Stock of Uneven Progress. Rome: FAO.

79. Hedenus F, Wirsenius S \& Johansson DJA (2014) The importance of reduced meat and dairy consumption for meeting stringent climate change targets. Clim Change 124, 79-91.

80. Oonincx DGAB \& De Boer IJM (2012) Environmental impact of the production of mealworms as a protein source for humans - a life cycle assessment. PLOS ONE 7, e51145.

81. Glover D \& Sexton A (2015) ) Edible Insects and the Future of Food: A Foresight Scenario Exercise on Entomophagy and Global Food Security. Brighton: IDS (Institute of Development Studies).

82. Collavo A, Glew RH, Huang Y-S, et al. (2005) House cricket small-scale farming. In Ecological Implications of Minilivestock: Potential of Insects, Rodents, Frogs and Snails, pp. 519544 [MG Paoletti, editor]. Enfield, NH: Science Publishers, Inc.

83. Despins JL \& Axtell RC (1995) Feeding behavior and growth of broiler chicks fed larvae of the darkling beetle, Alphitobius diaperinus. Poultr Sci 74, 331-336. 
84. Rao PU (1994) Chemical composition and nutritional evaluation of spent silk worm pupae. J Agric Food Chem 42, 2201-2203.

85. Dierenfeld ES (2002) Some preliminary observations on herbivorous insect composition: nutrient advantages from a green leaf diet? In Symposium of the Comparative Nutrition Society. Antwerp Zoo: Antwerp, Belgium.

86. Bird DM, Ho S-K \& Paré D (1982) Nutritive values of three common prey items of the American kestrel. Comp Biochem Physiol A Physiol 73, 513-515.

87. Kinyuru JN, Konyole SO, Roos N, et al. (2013) Nutrient composition of four species of winged termites consumed in western Kenya. J Food Compos Anal 30, 120-124.
88. Oyarzun SE, Crawshaw GJ \& Valdes EV (1996) Nutrition of the Tamandua: I. Nutrient composition of termites (Nasutitermes). Zoo Biol 15, 509-524.

89. Cerda H, Martinez R, Briceno N, et al. (2001) Palm worm: (Rhynchophorous palmarum) traditional food in Amazonas, Venezuela - nutritional composition, small scale production and tourist palatibility. Ecol Food Nutr 40, 13-32.

90. Ohtsuka R, Kawabe T, Inaoka T, et al. (1984) Composition of local and purchased foods consumed by the Gidra in Lowland Papua. Ecol Food Nutr 15, 159-169.

91. Ramos-Elorduy J, Moreno JMP \& Camacho VHM (2012) Could grasshoppers be a nutritive meal? Food Nutr Sci 3, 164-175. 